\title{
IMPLEMENTASI KEBIJAKAN BANTUAN PROGRAM INTERVENSI BAGI MASYARAKAT MISKIN TAHUN 2016
}

\section{Implementation Of Intervention Program Help Policies For Poor Communities In 2016}

\author{
Mukti Sumarsono ${ }^{1}$ \\ ${ }^{1}$ Magister Ilmu Administrasi Universitas Kadiri
}

\begin{abstract}
Abstrak
Penelitian dalam tesis ini dilatarbelakangi terkait pelaksanaan program intervensi bagi masyarakat miskin yang mana tujuan pelaksanaan program ini adalah menyejahterakan masyarakat miskin, sekaligus untuk menurunkan tingkat kemiskinan. Program intervensi bagi masyarakat miskin yang dilaksanakan diharapkan bisa efektif dalam pelaksanaannya dan bisa menurunkan angka kemiskinan.Kenyataan yang ada adalah tingkat kemiskinan yang ada di Kabupaten Tulungagung selama lima tahun terakhir meskipun mengalami penurunan namun persentasenya yang sangat kecil. Melihat fakta ini maka tidaklah sepadan dengan berbagai program pengentasan kemiskinan yang dijalankan. Rumusan masalah dalam penulisan tesis ini adalah (1) Bagaimana keefektifan bantuan program intervensi yang dilakukan oleh pemerintah terhadap penurunan jumlah masyarakat miskin. (2). Faktor-faktor apa saja yang menjadi pendukung maupun penghambat dalam pelaksanaan bantuan program intervensi bagimasyarakat miskin. Metode penelitian, penelitian ini menggunakan pendekatan kualitatif dengan jenis penelitian deskriptif. Kegiatan sosialisasi ternyata tidak semua desa melaksanakan kegiatan ini dengan berbagai alasan seperti takut terjadi protes dari warganya. Ada juga yang melakukan secara tidak resmi pada saat ada kegiatan di lingkungan. Sebenarnya pelaksanaan sosialisasi ini sudah ada petunjuk pelaksanaannya dimana dilakukan secara berjenjang dari level kabupaten dilanjutkan ke level kecamatan dan terus ke level desa. Pada saat di level desa inilah sering terjadi permasalahan.
\end{abstract}

Kata Kunci: Implementasi; Program Intervensi; Masyarakat Miskin

\begin{abstract}
The research in this thesis was motivated by the implementation of intervention programs for the poor where the aim of implementing this program was to improve the welfare of the poor, as well as to reduce poverty. The formulation of the problem in the writing of this thesis is (1) How is the effectiveness of the intervention program assistance carried out by the government to reduce the number of poor people. (2). What factors are supporting or inhibiting the implementation of intervention program assistance for the poor. The research method, this study uses a qualitative approach with the type of descriptive research. The dissemination activities turned out that not all villages carried out these activities for various reasons such as fear of protests from their citizens. There are also those who do unofficially when there are activities in the environment. Actually, the implementation of this socialization has already been carried out with implementation instructions which are carried out in stages from the district level and continued to the sub-district level and continued to the village level. At this time at the village level, problems often occur.
\end{abstract}

Keywords: Implementation; Intervention Program; Poor Community 


\section{A. PENDAHULUAN}

Indonesia sebagai salah satu negara yang memiliki penduduk terbesar ke empat di dunia, yang memiliki jumlah penduduk sekitar 260 juta jiwa. Indonesia saat ini terdiri dari 17.508 pulau, sekitar 6.000 diantaranya dihuni, terbagi menjadi 34 provinsi, lima di antaranya memiliki status yang berbeda. Provinsi dibagi menjadi 416 kabupaten dan 98 kota. Ada sekitar 300 kelompok yang berbeda etnis pribumi di Indonesia, dan 742 bahasa dan dialek yang berbeda (BPS, 2014).

Populasi penduduk Indonesia yang besar ini membuat Indonesia memiliki banyak sekali persoalan-persoalan rumit yang terjadi di masyarakat salah satunya kemiskinan. Masalah seperti ini sering terjadi di sebuah negara yang memiliki jumlah penduduk yang besar.

Pemerintah sebagai pemegang kekuasaan

tertinggi berhak untuk mengatur dan mengurus rumah tangganya sendiri. Sebagaimana yang tercantum dalam Undang-Undang Dasar Republik Indonesia Tahun 1945 yang mengamanatkan bahwa negara berkewajiban untuk melindungi segenap bangsa Indonesia dan memajukan kesejahteraan sosial dalam rangka mewujudkan keadilan sosial bagi seluruh rakyat Indonesia.

Fungsi dan tujuan negara adalah untuk mengusahakan kesejahteraan dan kemakmuran rakyatnya seperti yang tertuang dalam Pasal 34 ayat (1) UUD 1945 disebutkan bahwa "fakir miskin dan anakanak terlantar dipelihara oleh Negara". Maka secara tidak langsung dapat dikatakan bahwa semua orang miskin dan semua anak terlantar pada prinsipnya dipelihara oleh Negara, tetapi pada kenyataannya yang ada di lapangan bahwa tidak semua orang miskin dan anak terlantar dipelihara oleh Negara.

Undang-Undang yang dibuat oleh pemerintah sudah sangat baik dan memang yang dibutuhkan oleh masyarakat Indonesia, namun pada kenyataannya yang terjadi di lapangan saat ini belum sesuai dengan apa yang tercantum dalam Undang-Undang. Banyak sekali penduduk Indonesia saat ini yang masih hidup dalam keadaan miskin dan bahkan sangat miskin, yang membuat mereka tidak mampu dalam memenuhi kebutuhan mereka sehari-harinya. Kemiskinan itu merupakan sebuah konsep abstrak sehingga amat sulit didefinisikan. Itulah sebabnya kebanyakan dari mereka tidak berani menuliskan definisi kemiskinan itu secara eksplisit. Meskipun demikian, sekalipun amat umum, beberapa diantara mereka menuliskan juga definisi kemiskinan itu.

Kemiskinan merupakan hal yang kompleks karena menyangkut berbagai macam aspek seperti hak untuk terpenuhinya pangan, kesehatan, pendidikan, pekerjaan, dan sebagainya. Untuk mengubah kemiskinan dibutuhkan mental yang bagus.Kemiskinan memang dapat mengganggu kesejahteraan masyarakat, dan itu sangat tampak dari adanya rumah kumuh baik yang ada di pinggiran sungai atau tempat-tempat lainnya. Mungkin kemiskinan terjadi karena tidak dapat membiayai kehidupan secara langsung. Dan itulah yang terjadi sekarang ini, bahwa kemiskinan sekarang ada dimana-mana. Jika pemerintah tidak mengatasi masalah kemiskinan secepat mungkin, mungkin kemiskinan akan bertambah terus-menerus. Kemiskinan tidak hanya berdampak bagi para penduduk miskin tetapi juga berdampak bagi warga sekitarnya karena kemiskinan juga dapat meningkatkan tindakan kriminalitas.

Kemiskinan juga merupakan salah satu faktor penghambat pembangunan. Ia merupakan tolok ukur bagi sebuah negara apakah pembangunan yang tengah berlangsung dapat dinikmati oleh segenap warga negaranya tanpa memandang suku, agama dan ras, atau dengan kata lain pembangunan yang berlangsung bisa merata dalam masyarakat.

Kemiskinan bukan merupakan sesuatu yang berdiri sendiri, sebab ia merupakan akibat dari tidak tercapainya pembangunan ekonomi yang berlangsung. Dalam hal ini, kemiskinan akan makin bertambah seiring tidak terjadinya 
pemerataan pembangunan dalam masyarakat.

Tujuan Pembangunan utamanya adalah menyejahterakan masyarakat, yang pada akhirnya akan menurunkan tingkat kemiskinan di suatu wilayah. Jika pembangunan yang dilaksanakan ternyata berpengaruh kurang efektif atau bahkan tidak bisa menurunkan angka kemiskinan di suatu wilayah tentunya dipastikan ada permasalahan dalam pelaksanaannya.

Tingkat kemiskinan yang ada di Kabupaten Tulungagung selama lima tahun terakhir meskipun mengalami penurunan namun persentasenya yang sangat kecil. Melihat fakta ini maka tidaklah sepadan dengan berbagai program pengentasan kemiskinan yang dijalankan.

Angka-angka pada tabel. 1 menunjukkan persentase penurunan tingkat kemiskinan (P0) di Kabupaten Tulungagung sangat kecil dan kalau dibandingkan dengan program-program perlindungan sosial bagi pengentasan kemiskinan yang sudah diluncurkan, sangat tidak seimbang kemungkinan ada sesuatu yang kurang pas dalam pelaksanaannya. Kondisi ini terjadi merata di setiap wilayah kecamatan maupun desa.

Realita ini sangat menarik, sehingga penulis tertarik untuk mengangkat masalah kemiskinan. Adapun daerah yang dijadikan objek dalam penelitian ini adalah daerah Desa Tugu, Kecamatan Sendang Kabupaten Tulungagung.

Berdasarkan fokus penelitian yang telah ditetapkan tersebut, maka masalah penelitian dapat dirumuskan sebagai berikut :

1. Bagaimana keefektifan bantuan program intervensi yang dilakukan oleh pemerintah terhadap penurunan jumlah masyarakat miskin.

2. Faktor-faktor apa saja yang menjadi pendukung maupun penghambat dalam pelaksanaan bantuan program intervensi bagi masyarakat miskin.

\section{B. LANDASAN TEORITIS}

\subsection{Pembangunan Nasional}

Pembangunan Nasional adalah upaya untuk meningkatkan seluruh aspek kehidupan masyarakat, bangsa dan Negara yang sekaligus merupakan proses pengembangan keseluruhan sistem penyelenggaraan Negara untuk memujudkan Tujuan Nasional. Pelaksanaan pembangunan mencakup aspek kehidupan bangsa, yaitu aspek politik, ekonomi, social budaya, dan pertahanan keamanan secara berencana, menyeluruh, terarah, terpadu, bertahap dan berkelanjutan untuk memacu peningkatan kemampuan nasional dalam rangka mewujudkan kehidupan yang sejajar dan sederajat dengan bangsa lain yang lebih maju.

Tujuan pembangunan jangka panjang tahun 2005-2025 adalah mewujudkan bangsa yang maju, mandiri dan adil sebagai landasan bagi tahap pembangunan berikutnya menuju masyarakat adil dan makmur dalam NKRI berdasarkan Pancasila dan UUD 1945. Sebagai ukuran tercapainya Indonesia yang Maju, Mandiri dan Adil, pembangunan nasional dalam 20 tahun mendatang diarahkan pada pencapaian sasaran-sasaran pokok sebagai berikut.

1. Terwujudnya daya saing bangsa untuk mencapai masyarakat yang lebih makmur dan sejahtera.

2. Terwujudnya Indonesia yang demokratis berlandaskan hukum.

3. Terwujudnya rasa aman dan damai bagi seluruh rakyat serta terjaganya keutuhan wilayah NKRI dan kedaulatan negara dari ancaman baik dari dalam negeri maupun luar negeri.

4. Terwujudnya pembangunan yang lebih merata dan berkeadilan ke seluruh wilayah.

5. Terwujudnya peningkatan kualitas hidup dan kesejahteraan masyarakat di seluruh wilayah, termasuk berkurangnya kesenjangan antar wilayah dalam kerangka NKRI. 
6. Terwujudnya Indonesia yang asri dan lestari.

7. Terwujudnya masyarakat Indonesia yang bermoral, beretika dan berbudaya.

\subsection{Administrasi Publik}

Menurut Ali Mufiz yang dikutip oleh Sukidin dan Darmadi (2009:8), apa yang disebut ilmu administrasi publik adalah ilmu yang mempelajari kegiatan kerjasama dalam bidang-bidang yang bersifat publik. Oleh karena itu, administrasi publik merupakan cabang dari ilmu administrasi. Dengan demikian, semua teori, konsep, dan analisis yang berlaku dalam ilmu administrasi, juga berlaku bagi ilmu administrasi publik.

Istilah administrasi publik mempunyai berbagai macam definisi. Pemikiran pertama memandang bahwa administrasi publik sebagai suatu kegiatan yang dilakukan oleh pemerintah, yakni lembaga eksekutif. Misalnya Willoughby yang dikutip Dimock (Darmadi dan Sukidin, 2009:8) mencatat bahwa "Administrative function is the function of actually and interpreted by the judicial branches of government". Dari pernyataan tersebut menunjukkan bahwa administrasi publik itu hanya berkaitan dengan fungsi untuk melaksanakan hukum yang telah ditetapkan oleh DPR.

\subsection{Kebijakan Publik}

Pola kebijakan dalam pembangunan atau yang lebih dikenal sebagai kebijakan publik merupakan faktor penentu keberhasilan pembangunan salah satunya adalah dalam rangka terwujudnya peningkatan kualitas hidup dan kesejahteraan masyarakat di seluruh wilayah, termasuk berkurangnya kesenjangan antar wilayah. Kebijakan publik itu sendiri dapat dimaknai sebagai pemanfaatan yang strategis terhadap sumberdaya yang ada untuk memecahkan masalah-masalah publik atau pemerintah. Kebijakan publik merupakan suatu bentuk intervensi yang dilakukan secara terus menerus oleh pemerintah demi kepentingan kelompok yang kurang beruntung dalam masyarakat agar mereka dapat hidup, dan ikut berpartisipasi dalam pembangunan secara luas. Pengertian kebijakan publik menurut Chandler dan Plano dapat diklasifikasikan kebijakan sebagai intervensi pemerintah. Dalam hal ini pemerintah mendayagunakan berbagai instrumen yang dimiliki untuk mengatasi persoalan publik. Chandler dan Plano ( 1988 )

\section{METODE PENELITIAN}

Dengan melihat pada butir-butir rumusan masalah, tujuan dan manfaat penelitian, maka metode yang cocok untuk digunakan adalah metode penelitian kualitatif. Penggunaan metode kualitatif ini dipilih karena permasalahan secara spesifik belum jelas, holistik, kompleks, dinamis dan penuh makna sehingga tidak mungkin data pada situasi sosial dijaring dengan metode kuantitatif. Tempat penelitian adalah rumah tangga miskin yang ada di Wilayah Kecamatan Sendang Kabupaten Tulungagung. Dipilihnya wilayah ini karena persentase rumah tangga miskinnya yang masih tinggi meskipun berbagai program pembangunan sudah banyak dilaksanakan.

\section{PEMBAHASAN}

\subsection{Keefektifan Bantuan Program Intervensi yang Dilakukan oleh Pemerintah terhadap Penurunan Jumlah Masyarakat Miskin}

Program intervensi merupakan program perlindungan sosial bagi masyarakat miskin dalam berbagai macam bentuk seperti program jaring pengaman sosial seperti Bantuan Langsung Tunai (BLT) yang merupakan program konpensasi kenaikan bahan bakar minyak (BBM), Program Keluarga Harapan (PKH) yang diperuntukkan bagi masyarakat miskin yang mempunyai anggota rumahtangga sedang hamil, Program Jaminan Kesehatan Nasional (Jamkesmas), Program Beras Miskin (Raskin). Programprogram intervensi tersebut sampai sekarang masih terus berjalan dengan penyempurnaan-penyempurnaan. 
Awal pelaksanaan masing-masing program intervensi tersebut tidak bersamaan, melihat kebutuhannya seperti BLT mulai diluncurkan tahun 2005 kemudian program PKH mulai diluncurkan tahun 2008. Pelaksana program-program tersebut adalah pemerintah pusat lewat masing-masing kementerian berdasarkan Instruksi Presiden. Kementerian yang terlibat langsung adalah kementerian sosial dan kementerian kesehatan. Kementerian sosial menangani program intervensi BLT, $\mathrm{PKH}$ dan Raskin sementara kementerian kesehatan menangani program jaminan kesehatan nasional. Pelaksanaan kegiatan program intervensi tersebut berjenjang dari pusat ke provinsi terus ke kabupaten, dari kabupaten ke kecamatan sampai level desa sebagai eksekutor program intervensi.

Secara umum pelaksanaan program intervensi melalui tahapan-tahapan yang telah ditetapkaan sesuai dengan petunjuk teknis. Tahapan-tahapan ini meliputi sosialisasi program, verifikasi kelayakan rumah tangga sasaran di tingkat desa/kelurahan, pelaksanaan program, monitoring dan pelaporan.

Menurut Instruksi Presiden (Inpres) No $: 3$ Tahun 2008 yang mendapat Instruksi Presiden adalah kementerian dan Instansi pemerintah yang meliputi :

1. Menteri Koordinator Bidang Politik, Hukum dan Keamanan

2. Menteri Koordinator Bidang Perekonomian.

3. Menteri Koordinator Bidang Kesejahteraan Rakyat.

4. Menteri Keuangan.

5. Menteri Negara

Perencanaan

Pembangunan

Nasional/Kepala

Badan Perencanaan

Pembangunan

Nasional.
6. Menteri Sosial.

7. Menteri Dalam Negeri.

8. Menteri Komunikasi dan Informasi.

9. Menteri Negara Badan Usaha Milik Negara.

10. Jaksa Agung.

11. Panglima Tentara Nasioanal Indonesia.

12. Kepala Kepolisian Negara Republik Indonesia.

13. Kepala Badan Pusat Statistik

14. Kepala Badan Pengawasan Keuangan dan Pembangunan.

15. Para Gubernur.

16. Para Bupati/Walikota.

Ke 16 kementerian dan instansi pemerintah tersebut mendapat tugas dan kewajiban sesuai dengan kewenangan masing-masing. Sementara di level kabupaten, instansi yang terlibat dalam pelaksanaan program intervensi SKPD terkait, Kantor Pos, Pemerintah Kecamatan dan Pemerintah Desa.

\section{a. Sosialisasi Program Intervensi}

Sosialisasi program intervensi merupakan kegiatan penting untuk memperkenalkan program intervensi sebelum diluncurkan. Sosialisasi program intervensi dilaksanakan mulai dari level kabupaten yang mana turut diundang camat dan Satuan Kerja Perangkat Daerah (SKPD) terkait. Menurut informan 1, harapan dari hasil sosialisasi adanya pemahan yang seragam sebelum disampaikan ke level yang lebih bawah.

Camat yang telah mengikuti sosialisasi lebih awal bersama Musyawarah Pimpinan Kecamatan (Muspika) kemudian menindak lanjuti dengan mengadakan sosialisasi di tingkat kecamatan dengan 
mengundang kepala desa/kelurahan. Instansi lainnya yang turut diundang adalah PT POS di kecamatan.

Selanjutnya desa/kelurahan mengadakan sosialisasi program intervensi pada level desa/kelurahan dengan mengundang perangkat desa/kelurahan, Ketua RW, Ketua RT dan tokoh masyarakat. Namun yang menjadi permasalahan ada beberapa desa yang tidak mengadakan sosialisasi.

Pengakuan Informan 8 perangkat desa di Desa Nyawangan diadakan rapat dengan mengundang seluruh perangkat desa, ketua RW, ketua RT, anggota BPD dan tokoh masyarakat. Sebenarnya sosialisasi akan dilanjutkan sampai pada level RT dengan harapan pelaksanaan program intervensi dapat berjalan dengan baik. Namun menurut informan 9 perangkat desa di Desa Krosok sosialisasi tidak perlu harus dengan mengadakan pertemuan resmi, yang penting semua hal yang berkaitan dengan program intervensi dapat diterima masyarakat.

Berbeda dengan Desa Nglurup yang telah mengadakan sosialisasi secara resmi di balai desa namun warga yang menerima program intervensi merasa tidak mengetahui. Sosialisasi dinyatakan tidak berhasil disebabkan adanya pertentangan di tingkat RW dan RT. Penolakan ketua RT untuk menyampaikan informasi terkait siapa-siapa yang menerima program intervensi mengakibatkan warga menjadi korban.

Pelaksanaan sosialisasi program intervensi memang telah dilaksanakan di seluruh desa, namun tidak semua menindaklanjuti sampai pada level RW atau RT, sebagian mengadakan sosialisasi di forum resmi sedangkan sebagian lainnya mengadakan sosialisasi di forum tidak resmi atau hanya sekedar bincangbincang.

Ketidak berhasilan sosialisasi proram intervensi baik lewat forum resmi maupun tidak resmi adalah :

a) Kurangnya komitmen pelaksana sosialisasi, yang mana penyampai sosialisasi kurang jelas atau segan dalam menyampaikan materi sosialisasi.

b) Penyampaian informasi yang diterima tidak lengkap sampai ke sasaran program intervensi.

c) Pola pikir dari Rumah Tangga Sasaran (RTS) yang kurang memahami permasalahan, karena sebagian besar RTS adalah orang yang sudah tua dan berpendidikan rendah.

\section{b. Verifikasi Data untuk Program Intervensi}

Verifikasi data dimaksudkan untuk mengecek ulang tentang keberadaan dan kelayakannya sebagai penerima program intervensi. Jadwal Verifikasi yang melibatkan kepala desa, ketua RW dan RT dilakukan selama 2 (dua) hari untuk melakukan verifikasi daftar nama nominasi RTS sebelum dikirim ke Tim Program Intervensi di Kabupaten.

Verifikasi data dilakukan dengan cara mencoret nama RTS yang dianggap tidak layak menerima bantuan program intervensi dari daftar nominasi, dikukuhkan dengan membubuhkan tanda tangan dan cap/stempel ketua RT atau ketua RW atau Kepala Desa. Jika ada nama yang dianggap lebih berhak menerima bantuan program intervensi maka harus dibuatkan usulan nama RTS pengganti. Jumlah usulan baru ini tidak boleh melebihi dari total jumlah yang dibatalkan atau tidak layak seperti pindah, meninggal (tidak ada anggota rumah tangga lainnya) dan yang sudah tidak miskin lagi.

Verifikasi ini juga mengatasi pendapat dari beberapa kepala desa yang mengatakan data tidak layak karena sudah basi/kedaluwarsa. Realita yang ada, tidak semua desa memanfaatkan momen verifikasi data ini.

Bagi informan 6, Kepala Desa Krosok, verifikasi ini merupakan moment 
yang tepat untuk memperbaiki data, hasil verifikasi akan menghasilkan data yang valid dan up to date. Menurut informan 5, Kepala Nyawangan kenapa harus melakukan verifikasi kalo kenyataannya bisa secara langsung dipindah ke yang lainnya dengan membawa surat keterangan dari desa.

Realita verifikasi data, meskipun sebagian mengangggap tidak berguna seharusnya desa tetap harus melakukan verifikasi data, karena data tersebut dapat digunakan untuk basis data yang sewaktuwaktu digunakan untuk pelaksanaan program intervensi. Selain itu waktu pelaksanaan verifikasi data RTS seharusnya dijadwalkan dengan melihat beban tugas maksimum yang ada di desa. Bagi desa yang jumlah RTS sedikit mungkin masalah waktu tidak jadi kendala, sebaliknya desa yang memiliki jumlah RTS banyak tentunya akan kerepotan jika waktu yang disediakan terbatas. Dan jika perlu, pelaksanaan verifikasi bisa dianggarkan sehingga hasil yang dicapai bisa maksimal.

Kegagalan dalam proses verifikasi secara langsung akan memberikan dampak pada kualitas data RTS yang rendah dan bisa dipastikan jika data tersebut digunakan untuk program intervensi akan menimbulkan permasalahan. Ketidakberhasilan proses verifikasi daftar nama RTS oleh desa disebabkan :

a) Prosedur verifikasi kurang aplikatif bagi unsur pimpinan di desa.

b) Adanya pendapat yang mengatakan bahwa tanpa verifikasi data yang tidak layak langsung bisa dialihkan tanpa prosedur yang berbelit-belit.

c) Terjadi konflik di masyarakat ketika seorang RTS diputuskan untuk diganti karena memang sudah tidak layak lagi.

\subsection{Pendukung dan Penghambat Keberhasilan Pelaksanaan Program}

a) Sikap Pelaksana

Kebanyakan permasalahan yang muncul ketika program intervensi dijalankan adalah adanya ketidak tegasan dari pelaksana kegiatan terkait permasalahan yang muncul. Sebagai contoh, ketika program Bantuan Langsung Tunai banyak terjadi pelanggaran seperti pemotongan dengan dalih untuk pemerataan ataupun untuk sumbangan kepada yang lainnya. Menurut Instruksi Presiden Nomor 3 Tahun 2008 butir ke empat menyatakan, untuk melakukan tindakan hukum yang tegas sesuai dengan ketentuan peraturan perundang-undangan yang berlaku terhadap setiap orang, perusahaan atau badan hukum yang melakukan atau patut diduga melakukan penyimpangan dan penyelewengan dalam persiapan dan pelaksanaan program pemberian BLT. Dari Inpres No. 3 tahun 2008 ini sebenarnya bisa digunakan pijakan untuk bersikap tegas untuk segala jenis pelanggaran.

Melihat contoh kasus diatas maka segala bentuk pengurangan/pemotongan bantuan progrram intervensi yang diterima dengan alasan apapun tidak dibenarkan dan ini merupakan suatu pelanggaran. Pemotongan akan menodai tujuan utama pemberian bantuan program intervensi yaitu membantu masyarakat miskin agar tetap dapat memenuhi kebutuhan dasarnya, dan mencegah penurunan taraf kesejahteraan masyarakat miskin akibat kesulitan ekonomi.

Pemotongan dana bantuan program intervensi dilakukan dengan alasan-alasan sebagai berikut : (1) untuk pemerataan, ada 2 hal yaitu pemerataan untuk dibagi kepada warga miskinlainnya yang tidak mendapat bantuan, dan pemerataan untuk seluruh warga baik miskin maupun tidak mikin (budaya pemerataan), (2) untuk iuran transportasi ke lokasi mengambil dana/barang bantuan program intervensi, (3) sumbangan lainnya, misal lembaga sosial, dan (4) untuk biaya pengurusan surat-surat yang dibutuhkan untuk persyaratan administrasi untuk pencairan dana/barang dari program intervensi.

Menurut Meter dan Horn, begitu juga Edwards III, disposisi pelaksana menentukan keberhasilan program. Apabila implementor mempunyai disposisi 
yang baik, maka dia akan menjalankan kebijakan dengan baik.

b) Kondisi Sosial Ekonomi Masyarakat Berdasarkan hasil Susenas tahun 2015, rata-rata pengeluaran untuk konsumsi di kabupaten Tulungagung per kapita per bulan Rp. 322.000,-. Hasil Susenas terlihat riil, karena melakukan survei langsung ke rumahtangga. Susenas menggambarkan bahwa pendapatan yang begitu besar dilihat angka Produk Domestik Regional Bruto (PDRB) per kapita ternyata sebagian besaar dinikmati oleh kelas menengah ke atas.

Kondisi sosial ekonomi masyarakat di Kecamatan Sendang sebagian besar bekerja dengan status buruh dibanding status pengusaha. Di sektor pertanian, sebagian besar berstatus sebagai buruh tani dibanding sebagai pengusaha/petani. Di sektor industri, kondisinya tidak jauh berbeda dimana sebagian besar bekerja dengan status buruh di perusahaan yang ada kecamatan lainnya. Melihat kondisi ini dimana sebagian besar masyarakat bekerja dengan status buruh yang tidak bisa mempunyai banyak pilihan selain mengikuti apapun yang dikatakan pengusaha, maka ketika ada bantuan program intervensi, siapapun akan mau menerima bahkan sangat berharap untuk menerima. Begitu juga di sektor perdagangan, sebagiaan besar masyarakatnya berjualan pracangan kecilkecilan yang hanya bisa digunakan untuk memenuhi kebutuhan hidup hari itu juga. Mereka merasa kondisi sosial ekonominya sama rata.

Kecenderungan dari aparat pelaksana bantuan program intervensi melakukan pemerataan bantuan bagi semua rumah tangga dengan dalih supaya tidak ribut merupakan tindakan yang kurang tepat. Inilah salah satu faktor kenapa penurunan jumlah penduduk miskin di Kecamatan sendang berjalan sangat lamban.

Kriteria kemiskinan yang digunakan pemerintah dengan 14 variabel nya menjadi tidak efektif dan cenderung tidak digunakan. Metode rembug desa akhirnya menjadi pilihan sebagai sarana untuk menentukan kemiskinan seseorang, jadi hasilnya adalah kesepakatan. Maka wajar saja kalau setiap ada program intervensi selalu dibagi-bagi ke semua masyarakat hasil kesepakatan. Inilah yang menjadikan salah satu faktor penyebab kenapa penurunan angka kemiskinan di kecamatan Sendang berjalan lambat bahkan tidak seimbang dengan program intervensi yang diterima oleh masyarakat kecamatan Sendang.

Rembug desa terpaksa digunakan karena semua warga merasa layak untuk menerima bantuan program intervensi. Seperti pengakuan Informan 18 (responden yang tidak menerima program intervensi), dia mau menerima jika diberi,"rejeki tidak boleh ditolak" kata informan 18. Beda lagi pengakuan informan 17 (responden yang menerima bantuan program intervensi), dia mendatangi Ketua RT supaya mendapat bantuan program intervensi dengan berbagai argumen dan alasan. Sebelumnya informan initidak mendapat bantuan program intervensi dan setelah melakukan protes akhirnya bisa menerima bantuan program intervensi.

Berdasarkan pengamatan Penulis, informan 17 tidak layak untuk menerima bantuan program intervensi. Alasan pertama, informan 17 tidak masuk dalam kriteria 14 variabel dimana kondisi rumahnya sangat baik lantai rumahnya sudah bukan tanah, dinding sudah tembok dan bercat, listrik sudah pakai meteran, punya aset perhiasan emas dan sepeda motor. Alasan kedua, meskipun informan 13 seorang janda namun dia masih menerima pendapatan pensiunan dari suaminya yang sudah meninggal. Sesuai aturan, bahwa PNS/TNI/POLRI dan pensiunan (termasuk janda pensiunan) tidak berhak mendapat bantuan program intervensi.

Menurut Sabatier dan Mazmanian, dan juga menurut Meter dan Horn, kondisi sosial ekonomi mempunyai pengaruh dalam keberhasilan pelaksanaan program. Masyarakat yang terdidik akan lebih terbuka dalam meneima program, dibandingkan dengan masyarakat yang kurang terdidik. 
c) Situasi Politik Masyarakat

Dalam pelaksanaan bantuan program intervensi ternyata tidak semulus yang dibayangkan. Gelombang penolakan terhadap pelaksanaan bantuan program intervensi terjadi dimana-mana tak terkecuali di kecamataan Sendang. Beberapa pendapat yang sempat dikutip dari media.

"Menurut saya pemerintah sebaiknya menyerahkan bantuan program intervensi tidak dalam bentuk uang, yang paling sangat diharapkan warga masyarakat adalah adanya harga bahan kebutuhan pokok yang dapat terjangkau di segala lapisan masyarakat termasuk masyarakat yang kurang mampu, lagi pula penerima bantuan program intervensi seringkali tidak tepat sasaran". (Zamilatun, Jakarta)

“Bantuan Program intervensi adalah opsi yang tidak menyelesaikan masalah. Kalau kita sakit, kita ke dokter diberi obat dan sembuh. Beda dengan kemiskinan, bantuan program intervensi bukanlah obat tapi skedar minuman ringan. Habis minumannya haus lagi danmiskin kembali. Di luar kebutuhan harga naik lebih besar dibanding besaran yang diterima dari bantuan program intervensi" (Kayin Fauzi, Balikpapan)

Dalam situasi seperti ini tidak boleh faktor-faktor yang kurang obyektif menjadikan bahan pertimbangan dalam pelaksanaan bantuan program intervensi. Tidak diperbolehkan karena merasa berjasa ketika mendukung jabatan Kepala Desa sekarang dimasukkan sebagai rumah tangga penerima bantuan. Hal ini sangat sensitif di lingkungan kehidupan masyarakat di kecamatan Sendang.

Gelombang protes juga dilakukan sebagian perangkat desa, mereka beralasan trauma dengan kejadian konflik di masyarakat desa ketika pemerintah menggulirkan bantuan program intervensi. Pokok permasalahan yang mereka ungkap adalah data nama nominasi penerima bantuan program intervensi. Menurut mereka data nominasi penerima bantuan program intervensi tidak valid, untuk itu mereka menuntut harus dilakukan verifikasi data.

Setelah diadakan sosialisasi yang intensif gelombang protes bisa mereda karena mereka sudah mempunyai pemahaman termasuk bahwa verifikasi data merupakan salah satu tahapan yang harus dilalui sebelum bantuan program intervensi dijalankan.

Secara garis besar sikap politik masyarakat terbagi menjadi dua, yaitu :

- Mereka yang menolak

Mereka yang menolak beralasan data penerima bantuan tidak valid, sehingga banyak yang tidk tepat sasaran, mendidik masyarakat mempunyai sifat pemalas dan jiwa pengemis, menimbulkan konflik di masyarakat terutama yang tidak menerima bantuan, lebih baik diarahkan untuk membangun infrastruktur dan perluasan lapangan kerja.

- Mereka yang mendukung

Mereka yang mendukung menyampaikan bahwa ini program bantuan yang bagus untuk membantu masyarakat miskin mempertahankan posisinya supaya tidak jatuh lebih miskin sehingga mereka masih bisa menerima hak-haknya untuk menikmati kebutuhan hidupnya seperti berobat, menyekolahkan anaknya dsb. Bagi mereka yang sudah usia lanjut dan tidak mampu lagi bekerja ini merupakan jalan terbaik yang bisa digunakan.

d) Ketrampilan Pelaksana

Ketrampilan pelaksana berkaitan erat dengan sumber daya manusia yang mana sumber daya manusia menjadi kunci pokok keberhasilan implementasi sebuah kebijakan. Menurut Edawards III, walaupun isi kebijakan sudah dikomunikasikan secara jelas dan konsisten, tetapi bila implementor kekurangan sumber daya untuk melaksanakan, implementasi tidak akan berjalan efektif. Menurut Mazmanian dan Sabatier, tingkat komitmen aparat pelaksana untuk merealisasikan tujuan yang telah tertuang dalam kebijakan adalah variabel yang paling krusial. Aparat badan pelaksana harus memiliki ketrampilan dalam membuat prioritas 
tujuan dan selanjutnya merealisasikan tujuan tersebut.

Ketrampilan pelaksana selain ditentukan sumberdaya manusia yang ada juga sangat ditentukan sejauh mana kepedulian pelaksana dalam mensukseskan kegiatan ini. Kepedulian yang tinggi akan membawa keberhasilan yang nyata.

Komitmen dan ketrampilan sumber daya manusia dalam pelaksanaan bantuan program intervensi meliputi tahap sosialisasi, tahap verifikasi data, tahap pelaksanaan program dan tahap pelaporan.

Menurut informan 10, Ketua RW menyatakan bahwa tahap sosialisasi dilaksanakan hanya sekedar mengikuti tahapan yang ada dan mereka kurang begitu antusias untuk menerangkan tahap verifikasi.

e) Koordinasi Antar Pelaksana Program Intervensi

Dalam banyak program iintervensi, implementasi sebuah program perlu dukungan dan koordinasi dengan Satuan Kerja Perangkat Daerah (SKPD) lainnya untuk itu diperlukan koordinasi dan kerjasama antar SKPD demi keberhasilan suatu program.

Pembentukan tim koordinasi dilakukan melalui Pemerintah Kabupaten melalui sebuah surat keputusan. Tim Koordinasi Penenggulangan Kemiskinan Daerah (TKPKD) merupakan wadah untuk menyelesaikan berbagai masalah. Di awal pelaksanaan tugas tim koordinasi berjalan cukup baik, namun demikian ketika ada permasalahan pada saat sosialisasi kurang melibatkan unsur masyarakat lainnya seperti karang taruna, tokoh agama maupun tokoh masyarakat. Mereka kurang dalam menggalang tanggungjawab sosial dan partisipasi masyarakat dalam menyukseskan pelaksanaan program intervensi.

\section{E. KESIMPULAN DAN SARAN}

\subsection{Kesimpulan}

Hasil penelitian setelah dilakukan analisis dan pembahasan diperoleh beberapa faktor yang bisa mempengaruhi efektifitas pelaksanaan program intervensi bagi masyarakat miskin, yaitu sebagai berikut :

1) Sosialisasi program bantuan intervensi.

Sosialisasi program bantuan intervensi merupakan kegiatan awal sebelum pelaksanaan kegiatan dimulai, dengan dilaksanakannya sosialisasi membuat masyarakat mengetahui dan memahami terkait program dan sekaligus menghindarkan salah persepsi yang pada akhirnya menimbulkan permasalahan baru. Kegiatan sosialisasi ternyata tidak semua desa melakukan dengan berbagai alasan seperti takut terjadi protes dari warganya. Ada juga yang melakukan secara tidak resmi pada saat ada kegiatan di lingkungan. Sebenarnya pelaksanaan sosialisasi ini sudah ada petunjuk pelaksanaannya dimana dilakukan secara berjenjang dari level kabupaten dilanjutkan ke level kecamatan dan terus ke level desa.

2) Verifikasi Data.

Verifikasi data dimaksudkan untuk melihat dan mengecek ke lapang apakah nama-nama yang tercantum dalam daftar penerima manfaat program bantuan intervensi sudah benar dan sesuai dengan kondisi lapang. Namun banyak desa yang tidak melakukan tahapan ini dengan berbagai alasan seperti

- Prosedur verifikasi kurang aplikatif bagi unsur pimpinan di desa.

- Adanya pendapat yang mengatakan bahwa tanpa verifikasi data yang tidak layak langsung bisa dialihkan tanpa prosedur yang berbelit-belit.

- Terjadi konflik di masyarakat ketika seorang RTS diputuskan

3) Pendukung dan Penghambat.

a) Sikap Pelaksana.

Sikap pelaksana seharusnya tegas ketika terjadi pelanggaran prosedur pelaksanaan sehingga program bisa berjalan dengan benar. 
b) Kondisi Sosial Ekonomi Masyarakat.

Kondisi sosial ekonomi masyarakat yang stratanya hampir sama membuat pelaksana program mengalami kebingungan ketika jumlah penerima bantuan program tidak bisa mencakup semua sasara yang ada. Konsep tentang kriteria penerima manfaat program bantuan perlu disesuaikan dengan kearifan lokal.

c) Situasi Politik Masyarakat.

Meliputi mereka ada yang mendukung dan mereka ada yang menolak, pada situasi seperti ini maka sikap pelaksana harus profesional sesuai dengan prosedur yang ada dan tidak memihak ke siapapun. Berkembang isu bahwa perangkat desa/pelaksana program memberikan kemudahan bagi saudara/keluarga untuk prioritas masuk dalam daftar penerima manfaat bantuan progam.

d) Ketrampilan Pelaksana,

Ketrampilan pelaksana program dinilai kurang maksimal karena : (1) mereka segan dalam hal memberikan sosialisasi, (2) melakukan tahap verifikasi data rumah tangga sasaran dengan seadanya, (3) banyak kejadian pelanggaran prosedur seperti meratakan bantuan program intervensi, (4) pelaporan kegiatan yang tidak dijalankan karena ketidak tahuan pelaksana.

e) Koordinasi Antar Pelaksana Program Intervensi.

Pelaksanaan tugas tim koordinasi awalnya berjalan cukup baik, namun dalam pelaksanaannya selanjutnya kurang melibatkan unsur lainnya seperti karang taruna, perguruan tinggi maupun dunia usaha dalam menggalang tanggungjawab sosial dan partisipasi menyukseskan program intervensi. Koordinasi yang dilakukan harus bisa mengakomodir semua kepentingan dari para pelaksana tugas.

\subsection{Rekomendasi}

Berkaitan dengan pelaksanaan bantuan program intervensi yang mana sudah menjadi skala prioritas oleh pemerintah dalam usahanya untuk menurunkan angka kemiskinan, berikut beberapa hal yang perlu direkomendasikan, yaitu :

1. Implementasi Program

$\checkmark$ Pelaksanaan sosialisasi perlu dilakukan pada forum resmi dengan komitmen dan ketrampilan pelaksana yang tinggi, materi yang disampaikan haarus komprehensip, sehingga dapat mudah diterima oleh seluruh masyarakat

$\checkmark$ Proses verifikasi data nama calon penerima bantuan program intervensi harus dilakukan di seluruh desa dengan petunjuk dan standar yang sama sehingga bisa menhasilkan data yang homogen untuk seluruh desa yang ada.

$\checkmark$ Perlu dianggarkan biaya untuk pelaksaan nya sampai level RW/RT di setiap desa, hal ini penting karena muara akhir dari pelaksanaan program intervensi adalah wilayah RW/RT.

$\checkmark \quad$ Perlu lebih mengintensifkan terkait laporan setiap tahapan kegiatan, tidak hanya pada atasan langsung namun juga ke seluruh masyarakat yang ada.

2. Pendukung dan Penghambat Keberhasilan Program.

$\checkmark$ Sikap pelaksana harus jelas dan tegas utamanya terkait terjadinya pelanggaran dalam implementasinya, kalau perlu setiap pelanggaran yang ada di proses secara pidana.

$\checkmark$ Perlu tambahan indikator kemiskinan yang sifatnya mengakomodir situasi lokal, sehingga diharapkan hasilnya bisa lebih mengena pada sasaran yang ditetapkan.

$\checkmark$ Dukungan politik dari masyarakat tetap dibutuhkan, karena opada intinya program intervensi ini bertujuan untuk menurunkan tingkat kemiskinan. Jika muncul 
permasalahan segera dicari solusinya tanpa harus meniadakan progran intervensi.

$\checkmark$ Ketrampilan pelaksana program lebih ditingkatkan lagi dengan cara mengikuti training terkait program intervensi sehingga mereka mempunyai kemampuan dan komitmen yang tinggi yang pada akhirnya program intervensi bisa berjalan dengan baik dan benar. Selanjutnya perlu juga ditingkatkan tingkat kepedulian selaku pelaksana program sehingga program intervensi yang dijalankan bisa berhasil.

$\checkmark$ Koordinasi antar tim hatus ditingkatkan sehingga ketika ada permasalahan yang muncul segera bisa diselesaikan dengan cepat dan benar. Perlu memperluas jaringan dengan menggandeng unsur masyarakat lainnya seperti perguruan tinggi, tokoh agama/masyarakat maupun dunia usaha.

\section{F. REFERENSI}

Akil, S. 2001. Penataan Ruang dalam Rangka Mendorong Pengembangan Ekonomi Wilayah. Tangerang: Cipta.

Amar Syamsul, 1999.Analisis Ekonomi tentang kemiskinan dan implikasi Kebijaksanaan Pengentasannya di Pedesaan Propinsi Sumatera Barat, Pasca Sarjana Universitas Airlangga, Surabaya.

BPS, 2015, Tulungagung Dalam Angka, Tulungagung Jawa Timur.TNP2K, 2011. Profil Kemiskinan di Indonesia, dari data tnp2k.go.id/index.php?q=content/ke miskinan-di-indonesia, diunduh 19 Pebruari 2013.

Bappenas, 2012.Kemiskinan di Indonesia dan Penanggulangannya, dari www.bappenas.go.id/node/165/363

$0 /$ kemiskinan-di-indonesia-dan penanggulangannya, diunduh 19 Pebruari 2013.

Budi dan Ari. Menelusuri Simpul Penyebab Kemiskinan Masyarakat Desa. Dalam http//:google.com (Diakses tanggal 19 Januari 2009)

Badjuri, Abdul Kahar, dan Teguh Yuwono, 2002, Kebijakan Publik Konsep dan Strategi, Universitas Diponegoro, Semarang.

Badan Pusat Statistik, 2015, Penghitungan dan Analisis Kemiskinan Makro Indonesia Tahun 2015, BPS, Jakarta.

Departemen Sosial RI, 2008, Petunjuk Teknis Program Bantuan Langsung Tunai kepada Rumah Tangga Sasaran, Depsos RI, Jakarta.

Dunn, William N, 2000, Pengantar Analisis Kebijakan Publik (Terjemahan), Edisi Kedua, Gajah Mada University Press, Yogyakarta.

Dwijowijoto, R.N, 2003, Kebijakan Publik Formulasi, Implementasi, dan Evaluasi, Elex Media Komputindo, Jakarta.

Faisal, Sanapiah, 1990, Penelitian Kualitatif, dasar-dasar dan aplikasi, YA3, Malang.

Frank, Robert H, (1991). Microeconomics and Behaviour, Third edition, The Mc Graw Hill Companies Inc. USA.

Ginting, Jamilah, 2004. Analisis Faktor Penyebab Pendapatan Petani miskin di Kecamatan Deli Tua Kabupaten Deli Serdang,Pasca Sarjana Universitas Sumatera Utara.

Haryono suyono. Visi Kependudukan Berwawasan Kemanusiaan. Jakarta. DAMANDIRI: 2003. 
Howlett, Michael, dan M. Ramesh, 1995, Studying Public Policy: Policy Cycles and Policy Subsystems, Oxford University Press, New York.

Ibnussalam, 2002.Analisis Faktor-faktor Penyebab Kemiskinan masyarakat Desa (Suatu study pada Desa Bulucina, Tarutungsihoda-hoda dan Desa Gonting Jae Kecamatan Burumun Tengah Kabupaten Tapanuli Selatan), Pasca Sarjana USU Medan

Imawan, Wynandin, 2008, Pendataan Program Perlindungan Sosial PPLS 2008, Bappenas, Jakarta.

Islamy, Irfan, 2001, Prinsip-prinsip Perumusan Kebijaksanaan Negara, Penerbit Bumi Aksara, Jakarta.

----, 2015, Indeks Pembangunan Manusia Kabupaten Tulungagung Tahun 2015, Tulungagung.

Kismartini dkk, 2005, Analisis Kebijakan Publik, Universitas Terbuka Depertemen Pendidikan Nasional, Jakarta.

----, 2015, Laporan Akhir Pendataan Program Perlindungan Sosial
Kabupaten Tulungagung,

Tulungagung.

----, 2006, Metode Penelitian Administrasi, Alfabeta, Bandung.

----, 2007, Metode Penelitian Kuantitatif Kualitatif dan R\&D, Alfabeta, Bandung.

Molo Maccelinus, 1995. Kemiskinan : Konsep, Pengukuran dan Kebijakan;dalam Populasi No. 6 (2).

Moleong, Lexy J., 2002, Metodologi Penelitian Kualitatif, Penerbit Remaja Rosdakarya, Bandung.

Nurwidiastuti, (2001). Kemiskinan : Telaah Kritis dan Alternatif Penanggulangannya,Kajian Bisnis, 24 September-Desember 2001， STIE Widya Wiwaha.

Parsons, Wayne, 2005, Public Policy Pengantar Teori dan Praktik Analisis Kebijakan, Kencana Prenada Media Group, Jakarta.

Prayitno Hadi dan Arsyad L, 1987.Petani Desa dan Kemiskinan, BPFE, Yogyakarta. 